University of Nebraska - Lincoln

DigitalCommons@University of Nebraska - Lincoln

Faculty Publications: Agricultural Leadership, Education \& Communication Department
Agricultural Leadership, Education \& Communication Department

2012

\title{
Preparing Students for After-College Life: The Context
}

Kelli K. Smith

University of Nebraska-Lincoln, kksmith@binghamton.edu

Follow this and additional works at: https://digitalcommons.unl.edu/aglecfacpub

Part of the Other Public Affairs, Public Policy and Public Administration Commons

Smith, Kelli K., "Preparing Students for After-College Life: The Context" (2012). Faculty Publications: Agricultural Leadership, Education \& Communication Department. 58.

https://digitalcommons.unl.edu/aglecfacpub/58

This Article is brought to you for free and open access by the Agricultural Leadership, Education \& Communication Department at DigitalCommons@University of Nebraska - Lincoln. It has been accepted for inclusion in Faculty Publications: Agricultural Leadership, Education \& Communication Department by an authorized administrator of DigitalCommons@University of Nebraska - Lincoln. 
Published in New Directions for Student Services, no. 138 (Summer 2012), pp. 5-12; doi: 10.1002/ss.20002

Published online in Wiley Online Library: http://wileyonlinelibrary.com

Copyright (c) 2012 Wiley Periodicals, Inc. Used by permission.

\title{
Preparing Students for After-College Life: The Context
}

\author{
Kelli K. Smith
}

What role do colleges and universities play in preparing students for life after college? Much like parents who continually balance caring for their child versus carrying their child, colleges and universities must define their role in educating students in a way that will assist them not only during their time as students, but for the long term as well. Historical context informs the work of student affairs professionals and others in higher education in striking the right balance in helping prepare students for life after college, but significant new pressures face students, their mentors, and educational institutions today.

This chapter discusses the contexts that shape the work of student affairs professionals and their colleagues in helping students prepare for life after their undergraduate experience. That discussion begins with a brief review of the historical context and then moves to a lengthier review of the contemporary context.

\section{Historical Context}

Colleges in the United States have always prepared students for life after college, but the form of that preparation has changed over time. To some degree, the extent to which colleges and universities in the United States are expected to prepare students for life after college has roots in the doctrine of in loco parentis, a Latin phrase that means "in the place of a parent." The roots of in loco parentis extend beyond the American educational system, and the progression of the concept over time relates to the context in which student affairs professionals, faculty, and others prepare students for after-college life. 
Early in the history of the United States, colleges primarily followed the model of the English residential university system in which faculty were expected to attend to the intellectual, moral, social, and spiritual development of young students. The work of the faculty was focused on the formal curriculum and matters pertaining to it. This traditional model was in place from the establishment of Harvard in 1636 to approximately the last third of the nineteenth century, and it was quite different from the more laissez-faire treatment of students within German universities (Komives and Woodward, 2003). Later, however, faculty at leading institutions within the United States became more focused on research and scholarship and less engaged with the lives of students. This shift led to students creating a rich extracurricular life on their own. Responsibilities for regulating, disciplining, and advising students transferred from faculty to staff, and the earliest version of what is now known as student affairs emerged (Komives and Woodward, 2003). The holistic approach to educating students emerged and became predominant in higher education. At the same time, there was greater recognition of students' responsibilities for shaping their own learning and experiences both in and out of the classroom.

Another important historical development in American higher education relates to the relationship between college and careers. In the earliest days, students who attended college came largely from families of means and were not attending college to prepare for a career. The presumption was that these students would have roles as owners of businesses, leaders of the community, or respected members of the clergy. They attended college to assure their readiness as leading members of society. Over time, specialization and professionalization increased, which drove the need for more educated individuals in the workforce. The most elite institutions continued their emphasis on preparing leaders, while other institutions sprang up to serve the needs of the broader public and booming economy. These new institutions grew to be fairly explicit in linking their curricular and cocurricular offerings to career development. Indeed, even the elite institutions have moved in this direction.

\section{Contemporary Context}

The historical development of higher education and student affairs in the United States shapes contemporary practice in two important ways. First, it is generally recognized that faculty, student affairs professionals and other staff, and students share responsibility for the student experience and student success in higher education. Second, a holistic perspective informs the vision of what that experience should be and how success is defined.

This section of the chapter addresses several current issues and trends that, informed by historical developments, have an impact on contemporary practice. These issues and trends include: increased expecta- 
tions regarding accountability, renewed focus on learning, evolving student demographics, changing and challenging economic conditions, and building relationships in the face of disappearing boundaries and borders.

Accountability. Students, their families, legislatures, philanthropists, and the public-at-large have always had high expectations of higher education. In an era of rising costs, increasing options, and challenging economic horizons, those expectations have taken on the more concrete form of demands for accountability for their investments. The call for greater accountability manifests itself in a variety of ways related to the work of preparing students for life after college.

Family Involvement. Given that both students and their family members identify career goals as the number-one reason for attending college, it is not surprising to find that family members are increasingly involved in decisions regarding the education experiences of students. Parents, grandparents, guardians, and spouses or partners expect to be a part, and at times a significant part, of students' choices regarding college from beginning to the end, a phenomenon that is sometimes referred to as helicopter parenting (Young, 2003), and which some feel has reached a fevered pitch over the past several years (Golden, 2010).

While some in higher education decry what they perceive as the overinvolvement of family, others view family as partners. This development has led colleges and universities to begin marketing to both prospective students and their families, and it is not too surprising when family members want to meet with a career counselor alongside their student trying to decide upon a major.

Clearly, the nature of the university-student-family relationship has changed in recent years. This new relationship comes with both challenges and opportunities, such as increased access to staff and faculty, higher expectations for job placement, and a desire for value-added services and programs.

Another manifestation of heightened expectations of accountability is evidenced by recent regulatory activity regarding the gainful employment provisions included in Title IV of the Higher Education Act (United States Department of Education, 2011). While this activity has been centered on for-profit colleges, there are those in the not-for-profit sector of higher education who are concerned that their work may come under additional scrutiny as well (Epstein, 2010).

Learning. While in loco parentis has not disappeared completely as a guiding construct in higher education, universities in the United States have shifted their primary framework for working with students to learning and development (Bickel and Lake, 1999). Within this context, the student affairs profession has evolved to using more of an educational model than a paternalistic one.

Intentionally creating conditions that enhance student learning and development, as advocated in the seminal publication The Student Learn- 
ing Imperative: Implications for Student Affairs (American College Personnel Association, 1996), is critical for today's uncertain society. College graduates face a harsh economic climate, a plethora of new career choices, technologies and modes of communication that change daily, an enormously divided political landscape, and social forces that have altered family roles. Educating students on how to prepare for life after college, rather than coddling or controlling them, sets them up for success.

Student Demographics. To fully meet the duty of educating students and preparing them for life after college, it is essential for student affairs professionals to be familiar with the profile of the students they serve. National trends of student characteristics such as age, socioeconomic status, gender, and race have been well documented. However, it is important to examine such factors across institutional types and to be well informed regarding local demographics. Institutions of higher education differ widely, as do the student bodies they serve. For example, a small private institution in a rural area, an urban community college, and a large landgrant public institution would each, quite likely, produce unique student profiles. In addition to recognizing and understanding the profile of the student body they serve within their own institutional setting, student affairs professionals should also be familiar with general student characteristics that change over time (Komives and Woodard, 2003). Information on trends in student characteristics is readily available, yet "sadly, student affairs staff do not always take full advantage of such information" (p. 405).

While individual institutions each have their own unique student profi le, there are several national trends that are particularly salient with regard to preparing students for life after college. First, some argue that there is a constant need for direction and a lack of leadership and independence in the current generation of college students (Alsop, 2008). Whether real or not, the perception of the employers Alsop interviewed was that the current generation of college graduates lacked these characteristics. Another study of employers suggested students are prepared for their first job but not higher-level positions that require critical thinking, the ability to direct themselves, and management of uncertainty (Peter D. Hart Research Associates, 2008).

Second, students today are highly confident and individualistic. Twenge (2006) argues that, in addition to these characteristics, today's students possess self-perceptions regarding their abilities that are not congruent with reality. The author contends that while it might seem intuitive that the more individualistic one is, the more independent one would be, the reality is that the emphasis on uniqueness has led the current generation of college students to have an element of entitlement. Rather than having the ability to persevere, they tend to expect others to figure things out for them. There are, undoubtedly, implications for their lives after graduation here. Student affairs professionals are in prime positions to assist students in this regard. For example, oppor- 
tunities to help students develop a sense of agency and self-efficacy are plentiful in collegiate programs and services. Developing programs and services to foster realistic expectations, adaptability, and resiliency (Luthans, 2002) in college seniors would likely assist college graduates later in life (Murphy, Blustein, Bohling, and Platt, 2010).

Economic Conditions. Today's college graduates are entering into the most challenging economic environment in decades (Yousuf, 2009), though there are some signs that the job market is up a bit from its nearrecord lows of 2008-2010 (Stafford, 2011). It is not surprising given the condition of the economy that the debate regarding whether or not college is worth the investment has resurfaced (Carnevale, 2011; Vedder, 2011). However academicians and policy makers measure the relative merits of personal investment in higher education, it is clear that students (and their families) continue to see completing a college degree as an important pathway to building their future.

Though it is difficult to estimate how often individuals change both jobs and careers (United States Bureau of Labor Statistics, 2010b), the vast majority of today's students can certainly expect to have several changes in jobs and careers throughout their lifetime. Also, the rising rate at which new career fields emerge has skyrocketed. In 2010, the Bureau of Labor Statistics (BLS) began to develop and implement the collection of new data on green jobs (United States Bureau of Labor Statistics, 2010a). The impact of globalization and technology has also spurred the creation of new career paths. Therefore, teaching students how to choose a career or search for a job, for example, is critical. Additionally, it is imperative that students leave college fully prepared with the skill sets necessary to be successful in whatever career they choose.

Many students choose to attend graduate or professional school either immediately after their undergraduate education or several years down the road, and that is even more the case in the face of uncertain opportunities and rising expectations on the part of employers with regard to minimum requirements for positions. There is the question of whose responsibility it is to prepare students for that chapter of their lives. Is it their faculty advisor? A McNair program advisor? The career center? The student's responsibility on their own? Others? Much like other areas, cross-campus collaborations are needed to help students reach their full potential of preparedness for graduate education. Students need a solid grounding in research and writing during their undergraduate experience, areas that are worthy of concentrated effort even for students unsure of their postbaccalaureate plans, but especially when considering graduate or professional school. This may take the form of sponsored summer research appointments through the National Science Foundation at another university, or research on campus with a faculty member in their department of study. Such experiences, along with other activities outside of course assignments and projects, can be very helpful in informing decisions about graduate studies, fields of possible specialization, and careers. 
Advising and mentoring on the application process is also needed for students contemplating graduate education.

Building Relationships, Disappearing Borders. In the face of diffi- cult economic times, it is arguably more important than ever that student affairs professionals engage in partnerships with colleagues from across campus and throughout the community to create programs and services that fully prepare students for postgraduate life. The 2010 joint ACPA and NASPA task force report Envisioning the Future of Student Affairs placed further emphasis on collaborative partnerships:

\footnotetext{
In the new view of student affairs work, on-campus partnerships continue to be essential and challenging. Breaking down internal silos, while critical, is not enough. The mobility of students and the diversity of their experiences require a rethinking of the nature of student affairs collaborations. (American College Personnel Association and National Association of Student Personnel Administrators, 2010)
}

It is particularly important for colleagues in academic affairs and student affairs to collaborate creatively in enhancing student learning (Smith, 2005). There is research to support the idea that campus communities characterized by such collaborations offer an environment that promotes student success (Kezar, Hirsch, and Burack, 2002; Kinzie and Kuh, 2004; Schuh and Whitt, 1999).

The joint ACPA and NASPA task force also called for an expanded view of partnerships by encouraging colleges and universities to collaborate with entities beyond campus borders, such as private industry and community agencies, in addition to those outside local, state, and national boundaries. There are many programs that assist in preparing students for their later years that require such collaborations. U.S. students are studying abroad in unprecedented numbers. Service-learning programs offer students experiences locally, nationally, and internationally. Internships can occur in a student's hometown or in Tokyo, Japan. Implications for preparing students for life in a globalized society necessitate an expanded view of collaborative partnerships.

\section{Conclusion}

Henscheid (2008) identifies both academic experiences and cocurricular programs as important elements in helping prepare students for success after college. Further, Henscheid suggests that "attention also needs to be focused on making the connections between intellectual, personal, and social outcomes more explicit" (2008, p. 25). The authors of another study examining the transition of recent college graduates suggest additional ways in which institutions can prepare college seniors for the transition to careers. Programming for groups of students about to graduate to increase awareness of the common challenges and potential 
disappointments they might encounter, along with training modules to educate undergraduates about the goals of employers, could prove beneficial (Murphy et al., 2010).

What better profession is there to do this, and thus teach students how to live a fulfilling life outside the classroom, than student affairs? This chapter addresses the historical and contemporary context in which student affairs professionals and others prepare students for after-college life. Subsequent chapters discuss applicable theories and models of practice, overviews and case studies of programmatic and curricular approaches, and thoughts on the future in this area.

\section{References}

Alsop, R. The Trophy Kids Grow Up: How the Millennial Generation Is Shaking Up the Workplace. San Francisco: Jossey-Bass, 2008.

American College Personnel Association. The Student Learning Imperative: Implications for Student Affairs. Washington, DC: Author, 1996.

American College Personnel Association and National Association of Student Personnel Administrators. "Envisioning the Future of Student Affairs." Washington, DC: Authors, 2010.

Bickel, R. D., and Lake, P. F. The Rights and Responsibilities of the Modern University. Durham, NC: Carolina Academic Press, 1999.

Carnevale, A. “College Is Still Worth It." Inside Higher Education, Jan. 14, 2011. Retrieved June 29, 2011, from http://www.insidehighered.com/views/2011/01/14/ carnevale college is still worth it for americans

Epstein, J. "Going Ahead with Gainful Employment." Inside Higher Education, Apr. 21, 2010. Retrieved June 29, 2011, from http://www.insidehighered.com/ news/2010/04/21/gainful

Golden, S. "How Anxious Parents Affect Colleges, Students' Experience." USA Today, June 3, 2010. Retrieved June 29, 2011, from http://www.usatoday.com/news/ education/2010-06-03-IHE-anxious-parents-collegeo3 ST N.htm

Henscheid, J. M. "Preparing Seniors for Life after College." About Campus, 13(5), 2008.

Kezar, A., Hirsch, D., and Burack, C. (Eds.) Achieving Student Success: Collaboration between Academic and Student Affairs. San Francisco: Jossey-Bass, 2002.

Kinzie, J., and Kuh, G. D. "Going DEEP: Learning from Campuses That Share Responsibility for Student Success." About Campus, 9(5), 2004.

Komives, S. R., and Woodward, D. B., Jr. (Eds.). Student Services: A Handbook for the Profession (4th ed.). San Francisco: Jossey-Bass, 2003.

Luthans, F. "The Need for and Meaning of Positive Organizational Behavior." Journal of Organizational Behavior, 23, 2002.

Murphy, K. A., Blustein, D. L, Bohling, A. J., and Platt, M. G. “The College-to-Career Transition: An Exploration of Emerging Adulthood." Journal of Counseling and Development, 88, 2010. 
Peter D. Hart Research Associates. "How Should Colleges Assess and Improve Student Learning?” Washington, DC , 2008. Retrieved June 29, 2011, from http:// www.aacu.org/leap/documents/2008 Business Leader Poll.pdf

Schuh, J. H., and Whitt, E. J. (eds.). Creating Successful Partnerships between Academic and Student Affairs. San Francisco: Jossey-Bass, 1999.

Smith, K. K. "From Coexistence to Collaboration: A Call for Partnership between Academic and Student Affairs." Journal of Cognitive and Affective Learning, 2(1), 2005.

Stafford, D. “Job Prospects Brighten Slightly for 2011 College Graduates." Kansas City Star, May 20, 2011. Retrieved June 29, 2011, from http://www.kansascity. com/2011/05/08/2860013/future-brightens-for-2011-graduates.html

Twenge, J. M. Generation Me: Why Today's Young Americans Are More Confident, Assertive, Entitled-and More Miserable Than Ever Before. New York: Free Press, 2006.

United States Bureau of Labor Statistics, 2010a. “Measuring Green Jobs.” Retrieved Oct. 7, 2010, from http://www.bls.gov/green/home.htm

United States Bureau of Labor Statistics, 2010b. "National Longitudinal Surveys." Retrieved Nov. 25, 2010, from http://www.bls.gov/nls/nlsfaqs.htm\#anch41

United States Department of Education. "Obama Administration Announces New Steps to Protect from Ineffective Career College Programs." Retrieved June 29, 2011, from http://www.ed.gov/news/press-releases/ gainful-employment-regulations

Vedder, R. "For Many, College Isn't Worth It.” Inside Higher Education, Jan. 20, 2011. Retrieved June 29, 2011, from http://www.insidehighered.com/views/2011/01/20/ vedder going to college isn $t$ a smart decision for many young people

Young, J. R. (Jan. 31, 2003). "A New Take on What Today's Students Want from College." Chronicle of Higher Education, 49(21), A37, Jan. 31, 2003. Retrieved Oct. 21, 2010, from http://chronicle.com/article/A-New-Take-on-What-Todays/5696

Yousuf, H. "Job Outlook for 2010 Grads: Still Stinks." Cable News Network (CNN), Nov. 18, 2009. Retrieved June 29, 2011, from http://money.cnn.com/2009/11/17/ news/economy/college graduates jobs/index.htm

$\diamond \quad \diamond \quad \diamond \quad \diamond \quad \diamond$

Kelli K. Smith is assistant director of Career Services and an adjunct faculty member at the University of Nebraska-Lincoln. 